\title{
Pengaruh Variasi Pakan Sumber Energi terhadap PBBH, Konsumsi dan Konversi Ransum Kambing Kacang Jantan
}

Melkianus Sanan ${ }^{\mathrm{a}}$

${ }^{a}$ Fakultas Pertanian, Universitas Timor, Kefamenanu, TTU - NTT, Indonesia.

\section{Article Info}

\section{Article history:}

Received 8 Juli 2018

Received in revised form 9 Oktober 2018 Accepted 14 Oktober 2018

DOI:

https://doi.org/10.32938/ja.v3i4.544

Keywords:

Pakan Sumber Energi, PBBH, Konsumsi,

Konversi, Kambing Kacang

\begin{abstract}
Abstrak
Pengembangan usaha peternakan kambing kacang saat ini merupakan salah satu usaha yang dilakukan oleh masyarakat di Kabupaten Timor Tengah Utara dalam rangka menopang perekonomian keluarga. Penelitian bertujuan untuk mengetahui pengaruh variasi pakan sumber energi terhadap pertambahan bobot badan harian, konsumsi dan konversi ransum, kambing kacang jantan. Penelitian ini menggunakan 12 ekor ternak kambing kacang jantan yang sedang bertumbuh dengan kisaran umur 6 bulan sampai 12 bulan dengan ratarata berat badan awal adalah 11,77 kg. Rancangan yang digunakan dalam penelitian ini adalah rancangan acak kelompok (RAK) dengan 4 perlakuan dan 3 ulangan. Perlakuan terdiri dari R0 $=80 \%$ rumput alam $+20 \%$ lamtoro. $\mathrm{R} 1=50 \%$ rumput alam $+20 \%$ lamtoro $+30 \%$ jagung. $\mathrm{R} 2=50 \%$ rumput alam $+20 \%$ lamtoro $+30 \%$ dedak padi. $\mathrm{R} 3=50 \%$ rumput alam $+20 \%$ lamtoro $+30 \%$ gaplek. Hasil analisis sidik ragam menunjukkan bahwa pemberian jagung pakan sumber energi berpengaruh nyata $(\mathrm{P}<0.05)$ terhadap Pertambahan bobot badan harian, konsumsi dan konversi ransum. Dapat disimpulkan bahwa, konsumsi bahan kering, pertambahan bobot badan harian dan konversi ransum ternak kambing dapat ditingkatkan dengan penambahan jagung sebagai sumber energi.
\end{abstract}

\section{Pendahuluan}

Pengembangan usaha peternakan kambing kacang saat ini merupakan salah satu usaha yang dilakukan oleh masyarakat di Kabupaten Timor Tengah Utara dalam rangka menopang perekonomian keluarga. Usaha peternakan yang dilaksanakan umumnya masih bersifat skala kecil sehingga belum memberikan pengaruh yang signifikan terhadap perubahan ekonomi masyarakat.

Populasi ternak kambing diwilayah Kabupaten Timor Tengah Utara saa ini memperlihatkan tingkat produktivitas yang cukup, hal ini dapat dilihat data 2 tahun terakhir ini, pada tahun 2015 sebanyak 410,17 ekor dan tahun 2016 sebanyak 446,55 ekor (BPS Kab. TTU).

Pengembangan usaha peternakan kambing kacang banyak dipengaruh oleh berbagai faktor salah satunya ketersediaan pakan baik dari sisi kualitas maupun kuantitas dan dalam aplikasinya dibutuhkan penerapan sesuai dengan kebutuhan ternak sehingga produksi pertambahan berat badan dapat dicapai, maksimal. Formulasi pakan harus disesuaikan dengan kebutuhan nutrien ternak, jika tidak mampu memenuhi kebutuhan nutrien ternak akan mempengaruh pertumbuhan dan produktivitas, jika formulasi pakan tidak diperhitungkan dengan baik akan menambah biaya (cost) produksi pakan, sehingga perlu memperhatikan kebutuhan nutrien yang dibutuhkan. Ternak tersebut untuk pertumbuhan dan produktivitas ternak itu sendiri (Dwiyanto, 2005).

Pakan sumber energi adalah bahan makanan yang kaya akan kandungan nutrisi dan memiliki nilai kecernaan yang tinggi. Makanan penguat berfungs untuk meningkatkan dan memperkaya nilai gizi yang kurang pada pakan dasar. Pakan sumber energi yang digunakan dapat berasal dari tanaman seperti jagung, dedak padi dan ubi kayu. Tiap jenis pakan memiliki nilai nutrisi yang berbeda seperti jagung mengandung Energi metabolisme (EM) $4276 \mathrm{kkal} / \mathrm{kg}$ BK $88,27 \%$, PK $7,82 \%$, SK $2,14 \%$, BETN $38,72 \%$. Dedak padi mengandung (EM) $3679 \mathrm{kkal} / \mathrm{kg}$, PK 11,20\%, lemak 7,42\%, SK 8,82\%. Gaplek (EM) 4112 BK $87,28 \%$, PK 2,18\%, SK 0,91\%, LK 0,63\%. Pemberian pakan sumber energ pada ternak kambing diharapkan mampu meningkatkan produksi ternak kambing kacang, peningkatan berat badan harian ternak serta mengefisiensikan konversi ransum.

\section{Metode}

Penelitian ini dilaksanakan di Desa Nunmafo Kecamatan Insana, Kabupaten TTU. Alat yang digunakan dalam penelitian ini adalah timbangan ternak merek Weiheng dengan kapasitas $50 \mathrm{~kg}$, tingkat kepekaan 5 gram untuk menimbang ternak serta peralatan kandang. Ternak yang digunakan dalam penelitian ini adalah ternak kambing kacang jantan berjumlah 12 ekor, yang sedang bertumbuh dengan kisaran umur 6 sampai 12 bulan. Pakan yang digunakan dalam penelitian ini adalah rumput alam, daun lamtoro, tepung jagung, dedak padi, dan tepung gaplek (Tabel 1).

Penelitian ini menggunakan rancangan acak kelompok (RAK) terdiri dari 4 perlakuan dan tiap perlakuan diulang sebanyak 3 kali, yang terdiri dari $\mathrm{R}_{0}: 80$ $\%$ rumput alam $+20 \%$ lamtoro, $\mathrm{R}_{1}: 50 \%$ rumput alam $+20 \%$ Lamtoro $+30 \%$ jagung, $\mathrm{R}_{2}: 50 \%$ rumput alam $+20 \%$ lamtoro $+30 \%$ dedak padi $\mathrm{R}_{3}: 50 \%$ rumput alam $+20 \%$ lamtoro $+30 \%$ ubi kayu (dalam bentuk tepung)

Tabel 1. Komposisi Kimia Pakan yang Digunakan (\%BK)

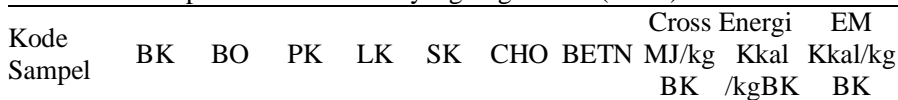

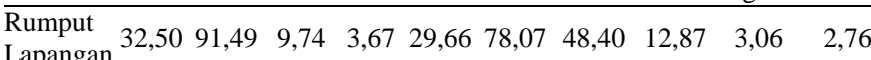

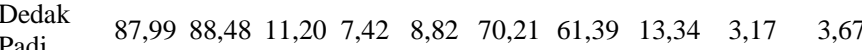

Padi

$\begin{array}{llllllllll}27,50 & 93,44 & 26,85 & 7,41 & 13,90 & 59,17 & 45,27 & 14,25 & 3,39 & 3,59\end{array}$

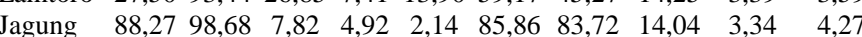

$\begin{array}{lllllllllll}\text { Gaplek } & 87,28 & 97,56 & 2,18 & 0,63 & 0,91 & 94,74 & 93,83 & 17,14 & 4,0 & 4,11\end{array}$
Data PBBH diperoleh dengan cara penimbangan setiap minggu, data konsumsi diperoleh dengan cara menghitung selisih antara pemberian ransum dan sisa ransum setiap hari sedangkan data konversi jumlah pakan yang dikonsumsi dibagikan dengan berat badan yang dihasilkan. Data yang diperoleh ini dianalisis menggunakan analisis sidik ragam, dilanjutkan dengan uji jarak berganda Duncan untuk melihat perbedaan antara perlakuan sesuai petunjuk Steel \& Torrie (1993)

\section{Hasil dan Pembahasan}

3.1. Pengaruh Perlakuan Terhadap Konsumsi BK Ransum

Konsumsi pakan adalah jumlah pakan yang diberi lalu dikurangi dengan jumlah pakan yang tidak di konsumsi (Kg/ekor/hari).

Tabel 2. Nilai Rataan Konsumsi BK Ransum Ternak Kambing Kacang.

\begin{tabular}{|c|c|c|c|c|c|}
\hline \multirow{2}{*}{ Perlakuan } & \multicolumn{3}{|c|}{ Ulangan } & \multirow{2}{*}{ Jumlah } & \multirow{2}{*}{ Rataan } \\
\hline & 1 & 2 & 3 & & \\
\hline $\mathrm{R}_{0}$ & 0,74 & 0,72 & 0,77 & 2,24 & $0,74^{\mathrm{a}}$ \\
\hline $\mathrm{R}_{1}$ & 0,53 & 0,69 & 0,72 & 1,95 & $0,65^{\mathrm{ab}}$ \\
\hline $\mathrm{R}_{2}$ & 0,61 & 0,62 & 0,65 & 1,88 & $0,62^{\mathrm{b}}$ \\
\hline $\mathrm{R}_{3}$ & 0,66 & 0,61 & 0,63 & 1,91 & $0,63^{\mathrm{b}}$ \\
\hline
\end{tabular}

Hasil analisis sidik ragam menunjukkan bahwa konsumsi ransum ternak kambing kacang jantan berbeda nyata $(\mathrm{P}<0.05)$. Hasil uji Duncan menunjukkan bahwa perlakuan $R_{0}$ memiliki konsumsi $B K$ lebih tinggi dari $R_{1}, R_{2}$, dan $R_{3}$ (Tabel 3). Konsumsi BK, $\mathrm{R}_{0}$ : 0,74 $\mathrm{R}_{1}$ : 0,65 $\mathrm{R}_{2}$ : 0,62 $\mathrm{R}_{3}$ : 0,63. Hal ini karena pada perlakuan $\mathrm{R}_{0}$ Sumber energi dari bahan pakan rumput alam dan lamtoro belum mencukupi kebutuhan energi sehingga ternak terus mengonsumsi pakan untuk memenuhi kebutuhan dan sebaliknya pada perlakuan $R_{1}, R_{2}$, dan $R_{3}$ dapa mengonsumsi sedikit karena kebutuhan sumber energi ternak sudah terpenuh sehingga ternak mengonsumsi sedikit pakan yang diberikan. Hal ini sependapat dalam suatu pakan belum memenuhi kebutuhan energi yang diperlukan maka ternak tersebut akan mengonsumsi bahan pakan lebih banyak. dilanjutkan dengan pendapat Lu dkk., (2005) bahwa kambing membutuhkan serat pakan yang cukup untuk aktivitas dan fungsi rumen yang normal. Dalam rumen serat pakan mengalami degradasi oleh mikroba untuk menyediakan energi untuk mendukung hidup pokok, pertumbuhan dan reproduksi.

\subsection{Pertambahan Bobot Badan Harian (PBBH)}

Pertambahan bobot badan merupakan salah satu peubah yang digunakan untuk menilai kualitas pakan yang diberikan kepada ternak. Laju pertumbuhan ternak setelah disapih ditentukan oleh beberapa faktor. Faktor yang mempengaruhi pertambahan bobot badan antara lain potensi pertumbuhan dari masing-masing individu ternak dan pakan yang tersedia (Hasnudi \& Wahyuni, 2005). Pertambahan bobot badan dipengaruhi oleh beberapa faktor antara lain pakan, jenis ternak, umur, keadaan genetis lingkungan, kondisi setiap individu dan manajemen tata laksana (NRC, 2006). Rataan pertambahan berat badan harian dapat dilihat pada Tabel 3 .

Tabel 3. Nilai Rataan Pertambahan Berat Badan Harian (Kg/ekor/hari)

\begin{tabular}{|c|c|c|c|c|c|}
\hline \multirow{2}{*}{ Perlakuan } & \multicolumn{3}{|c|}{ Ulangan } & \multirow{2}{*}{ Jumlah } & \multirow{2}{*}{ Rataan } \\
\hline & 1 & 2 & 3 & & \\
\hline $\mathrm{R}_{0}$ & 0,01 & 0,01 & 0,01 & 0,05 & $0,01^{\mathrm{b}}$ \\
\hline $\mathrm{R}_{1}$ & 0,04 & 0,04 & 0,05 & 0,14 & $0,04^{\mathrm{a}}$ \\
\hline $\mathrm{R}_{2}$ & 0,03 & 0,01 & 0,02 & 0,08 & $0,02^{\mathrm{ab}}$ \\
\hline $\mathrm{R}_{3}$ & 0,05 & 0,02 & 0,02 & 0,10 & $0,03^{\mathrm{ab}}$ \\
\hline
\end{tabular}
dengan Munier (2006), yang menyatakan apabila dalam pemberian ransum 
Hasil analisis sidik ragam menunjukkan bahwa keempat perlakuan berpengaruh nyata $(\mathrm{P}<0.05)$ terhadap pertambahan bobot badan harian ternak kambing kacang jantan. Hasil uji Duncan menunjukkan bahwa pertambahan bobot badan harian kambing kacang pada perlakuan $\mathrm{R}_{1}$ lebih tinggi dari $\mathrm{R}_{0}$ sebaliknya perlakuan $R_{2}$ dan $R_{3}$ relatif sama dengan $R_{1}$. Menurut Munier (2006), apabila dalam pemberian ransum pada ternak kebutuhan nutrientnya sudah terpenuhi maka akan memberikan pertambahan bobot badan yang tinggi. Dilanjutkan Nursasih (2005), bahwa pertambahan bobot badan ternak ruminansia sangat dipengaruhi oleh kualitas dan kuantitas pakan, maksudnya penilaian pertambahan bobot badan ternak sebanding dengan ransum yang dikonsumsi. Ternak yang sedang tumbuh membutuhkan pakan yang berkualitas untuk menunjang kebutuhan hidup pokok dan pertumbuhan yang dikehendaki. Salah satu kandungan zat makanan yang berperan dalam proses pertumbuhan adalah protein. Pemberian pakan yang kaya akan kandungan energi sangat dibutuhkan, karena kekurangan energi pada ternak muda dapat menghambat proses pertumbuhan maupun pencapaian dewasa kelamin (Sudarman $d k k$., 2008).

\subsection{Pengaruh Perlakuan Terhadap Konversi Ransum}

Konversi pakan merupakan jumlah unit pakan yang dikonsumsi oleh ternak dibagi dengan unit pertambahan bobot hidupnya per satuan waktu berdasarkan bahan kering (BK). Dalam konversi ransum, sebaiknya dipilih angka konversi terendah (Wahyudi, 2006). Faktor yang mempengaruhi konversi ransum khususnya pada ternak ruminansia antara lain kualitas pakan, besarnya pertambahan bobot badan, dan nilai kecernaan (Suci, 2011). Tabel 4 merupakan rataan konversi pakan ternak kambing yang diberi pakan sumber energi yang bervariasi.

Tabel 4. Nilai Rataan Konversi Ransum Ternak Kambing.

\begin{tabular}{|c|c|c|c|c|c|}
\hline \multirow{2}{*}{ Perlakuan } & \multicolumn{3}{|c|}{ Ulangan } & \multirow{2}{*}{ Jumlah } & \multirow{2}{*}{ Rataan } \\
\hline & 1 & 2 & 3 & & \\
\hline $\mathrm{R}_{0}$ & 42,59 & 46,81 & 42,13 & 131,53 & $43,84^{\mathrm{a}}$ \\
\hline $\mathrm{R}_{1}$ & 12,37 & 15,60 & 12,70 & 40,68 & $13,56^{\mathrm{b}}$ \\
\hline $\mathrm{R}_{2}$ & 16,07 & 34,41 & 26,76 & 77,25 & $25,75^{\mathrm{b}}$ \\
\hline $\mathrm{R}_{3}$ & 12,19 & 30,13 & 21,93 & 64,26 & $21,42^{b}$ \\
\hline
\end{tabular}

Hasil analisis sidik ragam menunjukkan bahwa perlakuan berbeda nyata terhadap konversi ransum. Rata-rata nilai konversi pada masing-masing perlakuan adalah $\mathrm{R}_{0}: 43.84, \mathrm{R}_{1} .13 .56, \mathrm{R}_{2}: 25.75, \mathrm{R}_{3}: 21.42$. Hasil uji Duncan menunjukkan bahwa perlakuan $\mathrm{R}_{1}$ memiliki konversi pakan terbaik sebaliknya $\mathrm{R}_{0}$ memiliki konversi pakan lebih jelek, sedangkan $\mathrm{R}_{2}$ memiliki konversi pakan relatif sama dengan $R_{1}$ dan $R_{3}$. Ternak perlakuan $R_{1}$ lebih efisien menggunakan pakan untuk meningkatkan berat badan karena membutuhkan pakan $13.5609 \mathrm{~kg}$ untuk memenuhi satu satuan bobot badan. Sebaliknya $\mathrm{R}_{0}$ membutuhkan $43.8451 \mathrm{~kg}$ BK tidak efisien memanfaatkan pakan untuk memenuhi satu satuan bobot badan.

Hasil penelitian pada perlakuan $\mathrm{R}_{1}$ menggambarkan bahwa penambahan pakan sumber energi (jagung) dapat berpengaruh terhadap konversi ransum. Nilai konversi ransum pada $\mathrm{R}_{1}$ menunjukkan bahwa pakan yang dikonsumsi efisien digunakan untuk meningkatkan PBBH. Hal ini diperkuat oleh Martawidjaja (2001) yang menyatakan bahwa konversi ransum dipengaruhi oleh kualitas pakan dan pertambahan bobot badan. Nilai konversi ransum menunjukkan jumlah pakan yang dikonsumsi untuk menghasilkan bobot badan, konversi yang rendah diikuti dengan peningkatan bobot badan menunjukkan pakan yang digunakan efisien (Julianto, 2003).

\section{Simpulan}

Konsumsi bahan kering, pertambahan bobot badan harian dan konversi ransum ternak kambing dapat ditingkatkan dengan penambahan jagung sebagai sumber energi.

\section{Pustaka}

Badan Pusat Statistik Kabupaten. Belu. 2016. Kabupaten Belu dalam angka Tahun 2016. BPS Kab. Belu

Dwiyanto. 2005. Mewujudkan Good Government Melalui Pelayanan Publik, Yogyakarta: Gajah Mada University Press.

Hasnudi \& T. H. Wahyuni. 2005. Pengaruh penggunaan hasil sampingan industri kelapa sawit dan limbah pertanian terhadap performans dan bobot potong domba sei putih. J. AGRIPET. 1(1): 1-17.

Julianto. 2003. Pengaruh Pemberian Urea Molases Blok sebagai Pakan Suplemen terhadap Pertumbuhan Pedet PFH Jantan. Skripsi. Fakultas Pertanian. Surakarta: Universitas Sebelas Maret.

Lu, C., J. R. Kawas. and O. G. Mahgoub. 2005. Fiber digestion and utilization in goats. Small Rumin. Res. 60:45-65.

Martawidjaja. 2001. Pengaruh Tingkat Protein Ransum Terhadap Penampilan Kambing Persilangan Boer dan Kacang Muda. Dalam : Prosiding Seminar Nasional Teknologi Peternakan Daerah Veteriner.

Munier. 2006. Pertambahan bobot hidup harian kambing peranakan etawa $(P E)$ betina yang diberikan pakan tambahan gamal. Balai pengkajian penelitian ternak Sulawesi tengah.
National Research Council (NRC). 2006. Nutrient Requirements of Small Ruminants (Sheep, Goats, Cervids, and New World Camelids). Washington, D.C: National Academic Press.

Nursasih. E. 2005. Kecernaan zat makanan dan efisiensi pakan pada kambing Peranakan Etawah yang mendapat ransum dengan sumber serat berbeda. Skripsi. Fakultas Peternakan. Bogor: Institut Pertanian Bogor.

Steel, R.G.D. \& J.H. Torrie. 1993. Prinsip dan teknik kerja secara nasional. Prosedur Statistika, Suatu Pendekatan Biometrik. Terjemahan: M. Syah. Jakarta: PT. Gramedia Pustaka Utama.

Sudarman, A., K. G. Wiryawan \& H. Markhamah. 2008. Penambahan sabunkalsium dari minyak ikan lemuru dalam ransum: pengaruhnya terhadap tampilan produksi domba. Med. Pet. 31(3): 166-171.

Suci, A., 2011. Analisis kecernaan pakan dengan sumber energi berbeda pada domba lokal jantan lepas sapih. Skripsi. Fakultas Peternakan. Bogor: Institut Pertanian Bogor.

Wahyudi. 2006. Pengaruh Substitusi Konsentrat dengan Campuran Ampas Brem dan Onggok dalam Ransum terhadap Performan Domba Lokal Jantan. Skripsi. Surakarta: Fakultas Pertanian, Universitas Sebelas Maret. 